\title{
Erratum to: Education and physical health trajectories in old age. Evidence from the Survey of Health, Ageing and Retirement in Europe (SHARE)
}

Liliya Leopold $\cdot$ Henriette Engelhardt

Published online: 17 February 2013

(C) Swiss School of Public Health 2013

Erratum to: Int J Public Health (2013) 58:23-31

DOI 10.1007/s00038-012-0399-0

The name of the second author has been misspelled. The correct name is Henriette Engelhardt.

The online version of the original article can be found under doi:10.1007/s00038-012-0399-0.

L. Leopold $(\bowtie)$

European University Institute, Via dei Rustici 2/11,

50122 Florence, Italy

e-mail: liliya.leopold@eui.eu

H. Engelhardt

Chair of Population Studies, University of Bamberg,

Lichtenhaidestraße 11, 96045 Bamberg, Germany

e-mail: henriette.engelhardt-woelfler@uni-bamberg.de 